\title{
Nye medier - ny journalistik? En pilotundersøgelse af net- nyhedsproduktionen i Danmark
}

\section{AF JANNIE MøLLER HARTLEY}

På baggrund af en pilotundersøgelse undersøger denne artikel forskningens hypoteser om netjournalistikken, med særligt fokus på den nordiske litteratur på området. Det argumenteres, at der med netmediet og netavisernes vækst ikke nødvendigvis er tale om ny journalistik; på den ene side bekræfter pilotundersøgelsen en opblødning i grænsen mellem journalister og læsere, samt ændringer i produktionen i form af kontinuerlig realtid redigering og publicering. Alligevel fremgår det, at mange af netjournalistikkens karakteristika er velkendte, og dermed bør udviklingen måske snarere ses som en radikalisering af nogle traditionelle journalistiske rutiner i nyhedsproduktionen. En radikalisering der indikerer, at nyheden i den digitale tidsalder kan ses som en dynamisk proces frem for et statisk produkt.

\section{Indledning}

Selvom der efterhånden er gået et årti, siden nettet for alvor gjorde sit indtog i verdens mediehuse, er den digitale teknologis indflydelse på journalistikken på netredaktionerne stadig et forholdsvist nyt forskningsområde. Indholdsanalyser har været dominerende i en litteratur, der med fokus på de teknologiske fremskridt påpeger, at journalistikken er under forandring (Domingo 2006). 
Den svenske forsker Michael Karlsson konkluderer på baggrund af et studie af nyhedsproduktionen på fire svenske aviser, at muligheden for at redigere i indholdet efter det er publiceret betyder, at digitale medier bryder med den traditionelle journalistiske arbejdsproces: Indsamling/redigering/distribution (Karlsson 2006: 195). I analoge medier har processen været skjult for publikum indtil distributionen. Publikum får ikke indsigt $\mathrm{i}$, hvordan et tv-indslag er klippet sammen, eller i hvilken rækkefølge en journalist har ringet kilderne hjem til en avisartikel. Publikum får kun det færdige produkt - trykt artikel eller færdigklippet indslag - at se. Disse forandringer i den journalistiske arbejdsproces kan i sidste ende få konsekvenser for, hvordan journalistik opfattes af publikum. Ifølge Karlsson findes der strukturelle forudsætninger for, at journalistikken fremover vil blive opfattet som en proces snarere end et færdigt produkt (Karlsson 2006: 199).

Teksten på en netavis kan endvidere forandres løbende i modsætning til en artikel i en trykt avis. Det er ikke bare dag-til-dag nyheder der produceres, men måske nærmere ,time-til-time nyheder“ (Karlsson 2006:36-37). Den kontinuerlige publicering på netaviserne betyder ifølge Karlsson at:

A) Nyhederne skifter plads, uden at der nødvendigvis sker noget nyt eller kommer ny information.

B) Nyheder kommer til, når kilder kommer med nyt materiale.

C) Nyheder kommer til, når de opfylder nyhedskriterierne.

D) Nyhederne skifter plads, når en nyhed bytter kontekst

E) Nyheder skifter plads, når der kommer nye informationer.

(Karlsson 2006:142-143).

I princippet har de digitale medier ubegrænset plads og kontinuerlig publicering. En avis på nettet har ikke et bestemt antal sider, der kan fyldes ud, og der er ikke kun én daglig deadline. Magne Lindholm argumenterer i en undersøgelse af norske netmedier, at netavisen er mere end blot en elektronisk papiravis. Han mener, at netmedier bevæger sig i retningen af portaler med indhold, der spænder langt bredere end blot nyheder, og han foreslår, at netavisen ses som en interaktiv database i konstant forandring (Lindholm i Ottesen 2008: 54). 
Dette underbygges endvidere af netmediets mulighed for hastig opdatering. Lindholms undersøgelse sammenligner netavis og papiravis ved at placere dem på en tidsakse, hvoraf det fremgår, at netavisen for det første har flere funktioner end papiravisen, særligt i form af interaktivitet og søgemuligheder. For det andet ligger netavisernes konkurrencefortrin særligt i opdateringsmuligheden, hvilket betyder, at tiden bliver konkurrencefaktor nummer ét, og aktualitet ser ud til at have forrang som prioriteringsprincip (ibid:49).

På linje hermed mener Niels Ole Finnemann, at netmediet kan ses som en femte mediematrice, ${ }^{1}$ som bygger oven på de allerede eksisterende. Således kan nettet ses som en sammensmeltning af de trykte mediers lageregenskaber og de elektroniske mediers transmissionshastighed. (Finnemann 2005:211). Egenskaberne ved produktionen er dermed ikke i sig selv unikke, men kombinationen synes ifølge Finnemann at forstærke tendenserne fra de tidligere mediematricer.

Eriksen og Ihlström (2000) besøgte tre svenske redaktionsrum i 1996 og 1999 for at analysere udviklingen i de forskellige webfeatures i sammenligning med henholdsvis trykte og elektroniske medier. De viser, at netaviserne gennemgår en udvikling fra at være en kopi af de trykte til mere „live dækning“, og jo længere tid der gik, synes netavisen at konkurrere mindre og mindre med den trykte udgave. Journalisterne synes også at efterlade historier, som ikke var direkte relaterede til nyhedsstrømmen (Eriksen og Ihlström 2000:9), og der forekom en klar adskillelse mellem hårde og bløde nyheder og måder at finde dem.

Betegnelserne brugerinvolvering, brugergeneret indhold og interaktivitet er af forskning og medier udråbt som en af de grundlæggende forskelle mellem de gamle massemedier og de nye netbaserede medieformer. Publikum vælger selv, hvad de vil se/høre/læse, og hvornår og hvor de vil gøre det. Og ikke mindst fordi publikum selv er med til at skabe medieindholdet (chat, debat, blog, osv. kobles på traditionelle medier). På den måde er nettet med til at udviske grænsen mellem producenter og konsumenter (Nygren 2008:77).

Via blogs, mail, kommentarer kan man i langt højere grad end nogensinde før tilpasse indholdet i medierne efter brugernes øn- 
sker. Medieforskeren Axel Bruns understreger, at brugerinvolveringen er nødvendig, hvis medierne vil fastholde læserne i fremtiden, idet mange ikke længere er afhængige af de traditionelle nyhedsmedier for at få de daglige informationer. Læserens rolle er endvidere ændret til såkaldte „produsers“, en sammentrækning af de engelske ord 'user' og 'producer'. Læseren kan forbruge nyhederne og samtidig deltage aktivt i produktionen af dem (Bruns 2005:8).

Ida Willig (Schultz 2007) har fremsat en tese om, at segmentpressen har taget over fra omnibuspressen, og - fra at have et publicistisk udgangspunkt og anskue publikum som borgere, synes de danske medier gået i retning af en markedsorienteret logik, hvor publikum anskues som forbrugere. Netjournalistik bør måske ses i lyset af denne hypotese, idet de digitale medier har muliggjort en direkte måling af, hvad læserne vil have, samtidig med, at læserne i større grad kan sammensætte journalistisk stof efter ønske. Den direkte effekt af dette synes dermed i netjournalistikkens tilfælde snarere at være en øget tabloidisering. ${ }^{2}$

Lindholm mener dog, at man her bør skelne mellem den såkaldte åbne og skjulte interaktivitet, hvor førstnævnte berører klik på links og billeder, samt kommentar- og debatfunktioner. Dertil skal lægges den skjulte interaktivitet; hver gang en netartikel åbnes sendes identificerende information frem og tilbage mellem bruger og producent, særligt i form af målesystemer (Lindholm i Ottesen 2008: 51).

Dog viser flere undersøgelser, at interaktiviteten ikke for alvor har vundet indpas på netredaktionerne. Martin Engebretsen (2007) har undersøgt 15 skandinaviske netaviser for mængden af hypertekstualitet, interaktivitet og multimedialitet og sammenlignet disse med de trykte versioner af historierne, samt forskelle mellem tv-stationernes og avisernes websider. Han konkluderer, at mulighederne for at udforme en dybere, dynamisk og brugerkontrolleret journalistik på nettet kun udnyttes marginalt. Undersøgelsen viste ligeledes, at der var forskel på de skandinaviske lande, hvor Danmark viste sig længere bagud end Sverige og Norge (Engebretsen 2007: 14).

Alligevel synes forskningen at konkludere, at den digitale journalistik adskiller sig fra den analoge, både når det gælder priori- 
tering, præsentation/publicering og forholdet til læserne. Denne artikel undersøger disse hypoteser om netjournalistik eksplorativt via en pilotundersøgelse, og hypoteserne deler dermed denne artikel i tre dele. Disse skal dog ikke ses adskilt, men som forskellige dimensioner af samme fænomen. Forskellene, som peger hen imod at se nyhedsproduktion til nettet som en proces, som dybere og dynamisk snarere end statisk, er illustreret i figur 1. Hypoteserne i skemaet er naturligvis forenklede for visualisering og overskuelighed, og både tidligere og nuværende diskussioner om journalistisk produktion i den akademiske litteratur reflekterer spørgsmålets kompleksitet.

\section{Figur 1}

Visualisering af nyhedsanskuelsen $\mathrm{i}$ henholdsvis analoge og digitale medier

\begin{tabular}{|l|l|l|l|}
\hline & Publicering & $\begin{array}{l}\text { Prioritering og } \\
\text { præsentation }\end{array}$ & $\begin{array}{l}\text { Forholdet } \\
\text { til læserne }\end{array}$ \\
\hline $\begin{array}{l}\text { Analog } \\
\text { journalistik: } \\
\text { nyheden } \\
\text { som produkt }\end{array}$ & $\begin{array}{l}\text { Nyheder } \\
\text { publiceres, når der } \\
\text { er deadline med } \\
\text { fast spalteplads } \\
\text { eller tv-minutter. }\end{array}$ & $\begin{array}{l}\text { Nyheden } \\
\text { præsenteres som } \\
\text { et fast produkt, } \\
\text { hvor alle oplys- } \\
\text { ninger inden for } \\
\text { en given tidsramme } \\
\text { selekteres og } \\
\text { sammenskrives. }\end{array}$ & $\begin{array}{l}\text { Brugerne/læserne } \\
\text { ses som passive } \\
\text { modtagere af } \\
\text { information. } \\
\text { Reaktion i form } \\
\text { af læserbreve. }\end{array}$ \\
\hline $\begin{array}{l}\text { Digital } \\
\text { journalistik: } \\
\text { nyheden } \\
\text { som proces }\end{array}$ & $\begin{array}{l}\text { Nyheden } \\
\text { publiceres løbende } \\
\text { og der er dermed } \\
\text { ingen deadline } \\
\text { og ingen plads- } \\
\text { begrænsninger. }\end{array}$ & $\begin{array}{l}\text { Nyheden skrives } \\
\text { og redigeres } \\
\text { løbende, når } \\
\text { der kommer nye } \\
\text { oplysninger. }\end{array}$ & $\begin{array}{l}\text { Læserne er } \\
\text { aktive medspillere } \\
\text { i nyheds- } \\
\text { produktionen via } \\
\text { forskellige former } \\
\text { for interaktivitet. }\end{array}$ \\
\hline
\end{tabular}

Metodisk bygger meget af den eksisterende forskning i netjournalistik på indholdsanalyser. Nærværende pilotstudie bygger på datamateriale indsamlet ved et kortere observationsophold på en af de største danske netredaktioner, samt interview med chefer og redaktører ved andre større danske netredaktioner, herunder netaviser tilhørende 3 morgenaviser, to tv-stationer og et regionalt mediehus. Endeligt bygger undersøgelsen på indsamlet 
skriftligt materiale (både interne arbejdsdokumenter og offentlige artikler om emnet). Den kombination gav mig mulighed for at gå bag om redaktørernes hensigter og journalisternes fortællinger om, hvorfor de gør, som de gør, hvilket samtidig øger muligheden for at forstå - ikke blot hvordan netjournalistikken ser ud - men også, hvorfor netjournalistikken ser ud, som den gør. Det kan ligeledes argumenteres, at en undersøgelse af, hvordan nettet forandrer eller ikke forandrer journalistikken i en mere procesorienteret grad vanskeligt lader sig gøre ved udelukkende at studere produkterne. Pilotundersøgelsen kan dermed også give indikationer på de metodiske fordele ved observationsstudier og de spørgsmål, som en indholdsanalyse vil kunne svare på, forbliver således spørgsmål undervejs i artiklen.

Empirisk og metodisk ligger fokus på netavisernes hovedsider, og hypoteserne bør ses i denne ramme. Empirien er anonymiseret, således at det blot fremgår, om citatet stammer fra chef, redaktør, journalist eller jourhavende. Det bør her understreges, at dette er en pilotundersøgelse, og at formålet blot er at tage temperaturen på miljøet og herudfra udvikle grobund og forskningsspørgsmål til en mere dybdegående undersøgelse af feltet.

\section{Den kontinuerlige publicering - nyheden som proces 1}

Pilotstudiet bekræfter den ændrede publiceringsrytme på nettet, som også Karlssons analyse af nyhedernes løbende forandring viste. Den journalistiske proces er blevet speedet op, fordi de løbende deadlines stiller krav om at få nyhederne hurtigt ud. Dermed øges behovet for at nyversionere og opdatere nyhederne, efter de er publiceret første gang. I dansk netjournalistik er hastighed, ligesom Lindholm ser det i den norske, afgørende for nyhedsproduktionen. Det gælder om at komme før konkurrenten for alt i verden. Illustreret ved følgende citat:

„Vi kulegraver jo ikke kommunalreformen eller et andet emne på nettet - men vi lægger os i slipstrømmen af dem, kan man sige og formidler, hvad det er, der falder af i den forbindelse. Og så sådan rent personligt, eller som journalistisk succeskriterium, der er der så hurtigheden, det at 
være med på pletten, hvor det sker. Vi er for eksempel også begyndt at skrive, hvis vi ved, der falder dom klokken tolv $\mathrm{i}$ en sag, så øh ... tit kan sådan en dom ... sådan nogle sager de kører jo fra det sker - anholdelse, grundlovsforhør, retsmøder, bla bla bla ... der kan gå flere måneder, og der er et hav af småting - små mellemregninger og opfølgninger, vi laver nogle - Ritzau laver nogle. Så ligger de i sådan en lang liste. Det vi så er begyndt at gøre, det er, at den dag, der så falder dom, der skriver vi sagen sammen, og så copypaster vi bare dommen, når den kommer, og så har vi sagen. Det betyder, at vi kan have hele sagen rullet op, når dommen falder - på minuttet, ik.' “ (interview netjournalist/morgenavis).

Mit pilotstudie efterlader samtidig indtrykket af, at tærsklen for hvad der publiceres på netaviserne, på grund af den uendelige mulighed for lagring og den løbende publicering, er lavere end på de traditionelle medier, hvor der finder en omfattende daglig prioritering sted. Således kan det regionale medie bringe „mange flere lokale historier på nettet, som ikke ville have fundet vej til avisen“ (interview chef/regionalt mediehus), mens morgenaviserne på nettet ligeledes bringer stof, som kan være en nyhed i en times tid, men langt fra er stor nok til at ,holde hele dagen“ (interview redaktør/morgenavis). Det stiller dog spørgsmålet, om netaviser i højere grad prioriteres ud fra kriterier om kvantitet frem for kvalitet, hvilket dog kræver en større begrebsafklaring af netop disse to termer. Det er sandsynligt, at en analyse af indholdet på mediernes netaviser kunne give svar herpå. Det samme gælder for en eventuel diskussion af, om der med nettets fremvækst er tale om en større globalisering og lokalisering af journalistikken på samme tid.

Observationerne viste tydeligt, at opdateringer kom både regelmæssigt og løbende, og en historie lå sjældent samme sted mere end to timer, med mindre den var rigtig relevant, og der ikke var andet, eller hvis den bliver læst meget. Netavisen forandrede sig konstant. Forsiden kan desuden ses som tabloidavisernes spisesedler, med mulighed for løbende udskiftning for konstant at trække nye læsere til. Udviklingen på andre konkurrerende 
netaviser fra ind- og udland samt TV 2 News følges på skærme og tjekkes løbende hele dagen og forsidehistorierne skiftes løbende ud hele dagen - eller skrives om, hvis der sker en udvikling i den sag, der dækkes.

I den daglige produktion forekommer ofte internt kollegialt drilleri om, hvilke historier der får flest hits. Det afstedkommer blandt andet "forhandlinger“ om, hvilke forsidehenvisninger der skal være på forsiden til de andre sites. Det skal ifølge den jourhavende gerne være et blandet miks - det går for eksempel ikke, at der er for mange historier fra et bestemt nichesite eller for mange kuriøse historier på forsiden. Selvom disse trækker mange klik.

„Der er ingen bestemte retningslinjer for egenhistorier på forsiden, men den skulle gerne være et godt 'mix'. Vi skal jo tage hensyn til alle vores undersites (de historier tæller også med som vores egne historier). Men det ville også være dumt ikke at tage en vigtig fælleshistorie - bare fordi det er Ritzau. (jourhavende netredaktion/morgenavis).“

„Det rette miks“ består ifølge den jourhavende af to slanger ned over siden. Den ene slange består stof fra bureauer og TV 2 News, mens den anden slange gerne skal være egenproduceret stof. Hertil tages en del af stoffet dog fra andre platforme i samme medieorganisation. Den samlede egenproduktion udgør herudfra at dømme en relativ lille del, hvilket udenlandske undersøgelser også bekræfter (Neuberger et al. 1997, Eriksen og Ihlström 2000 og Quandt i Paterson og Domingo 2008). Således kan netjournalister måske i højere grad betegnes som distributører af nyheder produceret af andre journalister på andre platforme. Karlsson mener, at faserne indsamling/redigering/publicering i den journalistiske produktion forsvinder i netjournalistikken, men spørgsmålet er, om de snarere opsplittes og forstærkes hver for sig på forskellige medieplatforme. Et spørgsmål, som kræver yderligere og mere komparative empiriske observationer. 


\section{Den løbende redigering og realtidsdækning - nyheden som proces 2}

Den løbende redigering og publicering som beskrevet ovenfor, bedrives i realtid og fuldt offentligt, hvilket er mere beslægtet med TV's livesending end avisers 24 timers rytme. På danske netaviser sker der således en løbende redigering, og redaktørerne understreger, at nettet netop er godt til den løbende opdatering, og sådanne historier kan ledsages af en „vi følger historien“. Fænomenet er langt fra nyt, men de digitale medier kan ses som redskabet til den optimale virkeliggørelse af en journalistik i en mere flydende og dynamisk form, som også hypoteserne fra forskningslitteraturen peger på. Med andre ord sker der en radikalisering af hurtighedskriteriet/realtidskriteriet i en sådan grad, at der er minimal tidsmæssig afstand fra at en begivenhed indtræffer til redigeringen og distributionen heraf.

Journalister på danske netredaktionerne lægger ofte selv deres historier ud (interview redaktører). Oftest med opdateringer, men også med hele historier. Når historien er ude, bliver den nogle gange redigeret i form af opdateringer. Ifølge en forsidevagt (den journalist, som prioriterer netavisens forside), sker det „for at spare tid." Både journalister, jourhavende og redaktører giver udtryk for, at læserne af nyhederne på nettet accepterer denne løbende redigering.

„Vi har nogle gange diskuteret, om man skulle vente med at lægge historier på, til man havde flere oplysninger. Men der jo også noget signalværdi i det. Det her er et site, hvor der sker noget, og som hele tiden bliver opdateret." (Jourhavende på netredaktion/morgenavis).

Citatet illustrerer en modsætning mellem grundighed og hurtighed, hvor sidstnævnte, når det gælder netjournalistik, synes at vinde i den daglige forhandling. Endvidere synes den løbende redigering at føre til en konstant jagt på nye vinkler, således at den høje aktivitet kan holdes oppe.

Et eksempel på dette er en historie fra Ekstra Bladet om en politimand, der chattede med en 13-årig pige på nettet. Den disku- 
teres flittigt og løbende af netjournalisterne på netavisen for at finde nye vinkler, der kan følges op med. Nye vinkler er også afgørende, fordi andres historier kan gøres til fælleshistorier og med nye vinkler til netavisens egne. De hyppige skift og jagten på nye vinkler hænger naturligvis sammen, og handler også om kroner og ører. Fra en redaktør på én af netavisens nichesites lyder det tværs gennem lokalet til forsidevagten, da politiet kan oplyse, at politimanden er blevet sigtet, at 'hun bør gøre det til en ny historie, frem for blot en opdatering'. Dermed kan netavisen få flere klik. Forsidevagten konstaterer over for kollegaen, at der jo ikke er så meget nyt, men laver alligevel en ny historie.

Dette synes også at have effekt på journalisternes stofområder. Observationerne i dette pilotstudie viste, at netjournalisterne er generalister, og hvis de har et område, de holder særligt øje med, forklares det med en egen interesse, eller at journalisten synes det er væsentligt. Af redaktørerne beskrives netjournalister som en særlig art meget omstillingsvillige journalister, parate til at smide alt, når den store fælles nyhed breaker. Nyhedsstrømmen følges og tophistorien kan det ene øjeblik være en kriminalhistorie, mens den det næste er en udland eller sport. Den daglige faglige produktion i forskellige stofområder kan dermed også betegnes som dynamisk og ikke-statisk. Og den løbende redigering og realtidsdækningen synes også at bekræfte en radikalisering af nogle rutiner i nyhedsproduktionen, der peger mod nyheden som en proces, som det findes beskrevet i litteraturen.

\section{Forholdet til Iæserne - nyheden som proces 3}

Brugerinvolvering og interaktivitet indtager en prominent plads $\mathrm{i}$ forskningslitteraturen om netjournalistik. Men ét er teorien om interaktivitetens muligheder, og noget andet er den praktiske virkelighed på netredaktionerne. I Danmark forsøger journalister og redaktører at tage brugerinvolveringen til sig på forskellige måder, i forskellig grad og med visse forbehold. Debatforum trives mange steder, men på flere medier synes udviklingen dog at gå i retningen af mere kontrol med interaktiviteten, og flere medier pusler med tanken om at fjerne anonymiteten (interview redaktører). Dette sker som følge af erfaringer med, at debatten kan 
være svær at styre, samt synes at blive domineret af et fåtal af de samme læsere. En fordel, som ofte nævnes i forbindelse med debatter og kommentarfora, er muligheden for at finde kilder og cases, hvilket især for de elektroniske medier har givet helt nye muligheder (interview redaktører).

Under hver historie finder læseren ofte journalistens mailadresse, og læserne kan tippe redaktionerne om gode historier. Endvidere kan brugeren klikke og korrigere journalisten, hvis han eller hun opdager fejl i artiklen. Dette sker også løbende, og de interviewede journalister udtrykte taknemmelighed over at være i kontakt med læserne, og få bekymringer over de fejl, der sneg sig ind en gang imellem. Det er prisen for at komme først, synes argumentet at være.

„Vi tror, at tolerancen for fejl fra læserne er større på nettet. Men vi hører fra dem, hvis vi har lavet for åbenlyse fejl“ (interview netjournalist/morgenavis)

Det interessante er her, at journalisterne synes at opfatte netjournalistik som en særlig form for journalistik, hvor læsere er mere tolerante end andre læsere. I kombination med den løbende redigeringsmulighed kan dette give en journalistik, hvor man i mindre grad behøver at tjekke kilder, før man skriver historien og ligeledes kan skrive, når et rygte florerer i nyhedsstrømmen. Journalisten kan blot rette til, hvis det viser sig at være forkert.

En anden form for interaktivitet har dog en anden og mindre synlig konsekvens for journalisterne - nemlig måleudstyret, der tæller publikums klik med musen. Det kommer udadtil helt konkret til udtryk på de „mest læste“-lister, der ses på langt de fleste netaviser.

På netavisen består redskabet af en række måleinstrumenter i form af et program, der på en skærm ved siden af redigeringsskærmen hele tiden giver den jourhavende mulighed for at følge med i, hvad læserne klikker på. Tallene siger ikke noget om, hvor længe en læser befinder sig for hvert klik. Redskabet bruges konstant til at flytte rundt på historierne - mest læste historier flyttes op eller får et billede, mens mindre læste reduceres til blot at ligge i en oversigt. På den måde finder en klar prioritering af histo- 
rierne sted, men denne er altså under stærk indflydelse af, hvad læserne gør og læser, minutter efter, de gør det. Hvis en historie ikke får så mange hits, kan den jourhavende prøve at „lokke“ læsere til ved at formulere en mere ,appetitlig“ rubrik. For eksempel en historie om „Succesfuld landing på Mars“ - der bliver til „Dansk udstyr landet på Mars“.

Rubrikken må meget gerne gøre læseren nysgerrig, og på den måde adskiller netjournalistik sig fra eksempelvis avisjournalistik, hvor rubrikken gerne skal være sigende for indholdet. Omvendt adskiller dette sig ikke fra tabloidavisernes spisesedler. En netredaktør mener, at det er en del af journalisternes job at gøre teksterne så spiselige for læserne så muligt.

„Vi er jo et gratis medie. Så på den måde synes jeg, det er rimeligt at lokke læseren på den måde. De betaler med klik." (interview nichesite-nyhedsredaktør morgenavis)

Medier har før gjort brug af både fokusgrupper og publikumsmålinger for at vurdere læserappel, blot er der med de digitale medier mulighed for at se læsernes ratings direkte og rimeligt præcist.

Ligeledes kan det indvendes, at både aviser, radio og TV har en lang tradition for debat, selvom dette naturligvis finder sted i varierende grad, og det rejser spørgsmålet, hvad det nye ved interaktiviteten i virkeligheden er? Det synes nærliggende, at der også når det gælder interaktivitet er tale om en intensivering af allerede eksisterende journalistiske normer i produktionen. Således har teknologien muliggjort læserdebat og kommentarer realtime, og det samme gælder læsermålinger, og frem for at give plads til en ny og udvidet kontakt med læserne, ses måske en journalistik styret af læserne og markedet, mens den traditionelle gatekeeper rolle og journalisten, som demokratiets vogter med væsentlighedskriteriet som våben, spøger i baggrunden. Når indholdet i stigende grad redigeres efter, hvad læserne vil have, synes det ifølge redaktørerne af netaviserne og de skrivende journalister at åbne op for flere historier om sex, vold og kendte, samtidig med at rubrikkerne skal sælge historien bedst muligt. Og netjournalistik bør måske snarere ses som en tabloidisering, frem for en ny 
og revolutionerende journalistik i tæt kontakt med læserne som deltagere i den journalistiske proces og medproducenter af den producerede journalistik. Et citat fra en redaktør illustrerer denne erkendelse på netaviserne:

\begin{abstract}
„(...) Vi bliver nødt til at udvide begrebet for, hvad avisen kan stå for. Men det skal ske i dyb respekt for de kerneværdier, der er blevet opbygget over mange år. Og det er altså den seriøse og troværdige tilgang til det. Og det er en lidt en svær øvelse, hvor det kræver, at man har tungen lige i munden, fordi hvis vi skriver for mange historier om sex og des lige, så er der også dem, der vil fravælge os, som er nogle kernelæsere for os, så det er en balancegang. Spørgsmålet er, om vi skal fokusere på alle dem, vi ikke har. Eller om vi i lige så høj grad skal tænke på alle dem, vi har“ (interview onlinechef/morgenavis).
\end{abstract}

Endvidere åbner den direkte kontakt med læserne i kombination med den løbende publicering op for en generel opfattelse af, at netlæsere i højere grad accepterer fejl. Dette må antages at føre til mere sjusk i journalistikken, hvilket ligeledes kan få stor betydning for læsernes opfattelse af journalistikken.

\title{
Diskussion
}

En gennemgående metafor i medieforskningen har været ideen om den journalistiske arbejdsplads som en fabrik - nyhedsfabrikken, med journalisterne som samlebåndsarbejdere. Nogle vil mene, at fabriksmetaforen er blevet mere aktuel end nogensinde på avisernes netredaktioner. Tydeligt er det i hvert fald, at en konstant deadline stiller krav om, at journalisterne kan arbejde i højt tempo med mange bolde i luften på samme tid, og at de kan betegnes som en form for ultra-generalister. Sikkert er det også, at netjournalistik på nogle måder er en variation af traditionel journalistik, og på andre måder adskiller sig væsentligt. Her bør realtidsfunktionen kombineret med en lagring af materiale fremhæves som features med særlig betydning for netjournalistikkens form. 
Pilotstudiet viser endvidere, at der i netjournalistik ses en særlig stor accept af fælleshistorier og ekslusivitetskriteriet (Schultz 2007) synes i den netjournalistiske praksis i særlig grad at handle om at være først og få de kilder, som de andre netaviser ikke har. Dette kan medføre nyhedsisomorfisme i det generelle nyhedsbillede; jagten på nye vinkler fører tilsyneladende og paradoksalt til flere af de samme historier og vinkler. Dette bør dog undersøges selvstændigt, før konklusioner kan drages.

At hurtighed indgår som et kriterium i den journalistiske produktion er langt fra nyt. Som Karlsson også bemærker, kan den måde netnyheder produceres på minde om det de 24-timers nyhedskanaler har stået for i mange år. Dog kan det tyde på, at hurtighedskriteriet får en særlig vægt i netnyhedsproduktionen, og at netmediet giver optimale vilkår for dette, idet der i hvert fald i første omgang ikke skal produceres billeder.

Netredaktører taler om nettets bredde snarere end dybde, idet nettet både giver mulighed for at linke til andre historie-universer, andre sites og for at brede historierne ud i form af mere fakta og baggrund. Netaviserne kan dermed, som Lindholm argumenterer, betegnes som databaser i løbende forandring. Der kan således frem for en hel ny form for journalistik med netmediet være tale om en radikalisering af nyhedsbegrebet og realtiddækningen til at udgøre selve fundamentet for den journalistiske produktion, idet andre journalistiske normer såsom dybde, grundighed og neutralitet nedtones, ændrer betydning i netjournalistikken eller henvises til andre platforme.

Dette pilotstudie indikerer på den ene side, at læseren kan følge produktionsprocessen i langt højere grad end før, har flere muligheder for at deltage i den, og at journalistikken redigeres og produceres via indirekte input fra læserne i form af klik. Spørgsmålet er, hvad dette betyder for journalisten, som hidtil har haft noget nær eneret på produktionen af nyheder og for journalistikken, som må se sine grænser blive udvidede, udvaskede eller på anden vis forandrede. På den anden side synes interaktivitets-begrebet, som har været beskrevet nærmest som en mirakelkur for den døende journalistik, nærmest at forstærke snarere end at afskaffe den journalistiske gatekeeper-rolle, idet der med nettet og de digitale mediers fremvækst kan argumenteres for et stadig 
større behov for at sortere, forklare og fortolke i informationsstrømmen. Med den stadig stigende hastighed i produktionen af nyheder må selve antallet af nyheder være nærmest eksploderet, og også når læseren kan deltage, sorteres der i indlæg, og netaviserne ansætter blogredaktører til dette formål eller gør det til en del af journalistens job. Ligeledes viser dette pilotstudie, at der også på netmediet finder en omfattende prioritering af stoffet sted, og at de redigerende af netaviserne, trods den ubegrænsede plads, stadig sammensætter „et godt mix“ med tophistorier, underhistorier etc.

På de tre dimensioner diskuteret i denne artikel synes der således ingen afgørende brud med eksisterende normer, men snarere ses en radikalisering af nogle normer og en nedtoning af andre i en grad, som kan ændre forståelsen af selve nyheden som produkt. For selvom formen har ændret nyhedsstrømmen, synes der i højere grad at være tale om, at teknologien og de digitale medier har muliggjort, at processen speedes op, både når det gælder respons fra læserne og nyhedsdækningen, hvilket har givet aktualitetskriteriet og breaking-news en stadig vigtigere rolle, særligt mærkbart naturligvis i selve netjournalistikken.

For at forstå denne udvikling, bør journalistikforskningen fremover gå fra at studere det specifikke og nye ved nettet og de digitale medier, til ligeledes at undersøge de interne forskelle mellem medieplatforme i sammenhæng med de andre faktorer som strukturerer mediemarkedet, eksempelvis rollemodsætninger som producent/distributør, langsom/hurtig, dagsordensættende/dagsordendækkende, generalister/specialister osv. Det er sandsynligt, at et nyt medie, som på den måde forstærker nogle eksisterende rutiner og normer, i en særlig grad vil påvirke andre dele af det journalistiske felt. Metodisk har pilotstudiet vist, hvordan etnografiske observationsstudier giver et særligt indblik i de journalistiske produktionsprocesser på nettet. De kvalitative interview med chefer og redaktører indikerer dog også, at der er forskel på medierne, og at mediehusenes forskellige strategier for produktion af netnyheder udmønter sig i forskellige normer og rutiner. Og pilotundersøgelsen efterlader næsten lige så mange spørgsmål som den besvarer, herunder specielt spørgsmål om mængden af nyheder, graden og mængden af egen-produktion 
og det såkaldte „shovelware“ samt den generelle nyhedsisomorfisme i det danske nyhedslandskab.

Tilbage står, at komparative observationer på netredaktioner kan give interessante indsigter i prioriteringen og den daglige produktion af netnyheder. Kombineres dette med en indholdsanalyse på tværs af medierne, vil forskningen komme flere skridt nærmere en forståelse af, hvordan journalistikken med internettets fremvækst forandres, omdefineres eller på anden vis ændrer hele eller dele af feltet.

Pilotundersøgelsen, som denne artikel bygger på, skal ses som forarbejdet til en større analyse i form af et Ph.d. projekt. Her er målet netop - via en komparativ etnografisk analyse af den journalistiske produktion med udgangspunkt i netjournalistikken i kombination med en indholdsanalyse af en række medier - at foretage et ydmygt skridt mod større balance mellem de teoretiske hypoteser om netjournalistik, formuleret ud fra de muligheder netmediet åbner for, og den netjournalistiske virkelighed.

\section{N O TER}

1. Ved mediematrice forstås kommunikativ infrastruktur og de fem mediematricer Finnemann ser er dannet omkring hhv. tale, skrift, bogtryk, analoge elektroniske medier og digitale medier (Finnemann 2005:12).

2. Den engelske medieforsker Colin Sparks (2000) har tre forskellige forståelser af begrebet tabloidisering:

For det første tabloidisering - som nyhedsproduktet i trykte aviser eller på tv, hvor vægten fjernes fra forhold indenfor økonomi, politik og samfund, og i stedet lægges relativt mere vægt på f.eks. sport, skandale, populærkultur og det private. For det andet kan tabloidisering forstås som det, at et medie skifter prioriteringer, væk fra nyheder og information, hen mod underholdning. Og for det tredje kan tabloidisering ses som en beskrivelse af smagløst indhold i en bestemt form for medie-output. Eksempelvis talk shows, som fokuserer på de forkerte emner med de forkerte gæster. Dermed ses den seriøse nyhedsjournalistik i høj grad kendetegnet ved emner, der vedrører de lokale såvel som internationale samfundsstrukturer: det kunne være 
politiske beslutninger og diskussioner, økonomiske forhold og udviklinger samt interessegruppers synspunkter.

De „seriøse“ nyheder henvender sig til seeren som borger i et samfund, som vedkommende skal tage stilling til og øve indflydelse på. Den tabloide journalistik tager i modsætning til den „seriøse“ langt mere udgangspunkt i emner udenfor de primære samfundsstrukturer, eksempelvis sport, underholdning og privatsfæren. Derved forholder en ekstremt tabloid nyhedsjournalistik sig ikke til modtageren som borger, mere som forbruger af et medieprodukt.

\section{REFERENCER:}

Bruns, Axel 2005: Gatewatching: Collaborative Online News Production (Digital Formations). New York: Peter Lang Publishing.

Domingo, David 2006: Ph.D. dissertation: Inventing online journalism: Development of the Internet as a news medium in four Catalan newsrooms. Universitat Autònoma de Barcelona. July 2006.

Engelsbrechsen, Martin 2006: "Shallow and Static or Deep and Dynamic? Studying the State of Online Journalism in Scandinavia”, Nordicom Review 2006 27(1): 3-16.

Eriksen, Lars Bo og Ihlström, Carina 2000: Evolution of the web-genre: The slow move beyond the print metaphor. I Proceedings of the $33^{\mathrm{rd}}$ Hawaii International Conference on System Sciences: Los Alamitos: IEEE.

Finnemann, Niels Ole 2005: Internettet $i$ mediehistorisk perspektiv. København: Samfundslitteratur.

Karlsson, Michael 2006: Nätjournalistikk, En explorative fällstudie av digitale mediers karaktarsdrag på fyra nyhedssajter, Lund Universitet.

Christoph Neuberger, Jan Tonnemacher, Matthias Biebl, and André Duck 1997: “Online - the future of newspapers?" Germany's dailies on the World Wide Web. Journal of Computer-Mediated Communication 1997: 4(1). Fundet november 2008 på: http://www.ascusc.org/jcmc/ vol4/issue1/neuberger.html.

Nygren, Gunnar 2008: Nyhetsfabriken journalistiska yrkesroller $i$ en förändrad medievärld. Lund: Studentlitteratur.

Lindholm, Magne 2008: „Hva er en nettavis?“ i Ottesen, Rune og Krumsvik, Arne H, Journalistikk i en digital hverdag. Kristianssand: Højskoleforlaget. 
Patterson, Chris and Domingo, David 2008: Making Online news, the ethnography of new media production. New York: Peter Lang.

Schultz, Ida 2007: „En sociologisk hypotese om dagspressens historiske udvikling“, Journalistica 2007: nr. 5.

Sparks, Colin (ed) 2000: "Introduction, Tabloid Tales: Global Debates over Media Standards”, Critical Media Studies. Oxford, N.Y: Rowman \& Littlefield. 


\section{English Abstracts}

\section{New Media - new Journalism?}

\section{- a pilotstudy of online newsproduction in Denmark}

\section{JANNIE MøLLER HARTLEY}

Based on a pilot study this article examines the research hypotheses in the field of online-journalism, with particular focus on the Nordic literature. It argues that the growth of online journalism and online newspapers is not necessarily the case of new kind of journalism; on the one hand, the pilot study confirms a blurring of the relationship between journalists and readers, and a change in the form of continuous real-time editing and publishing. Yet it appears that many of the characteristics of online journalism are well known, and thus, the development might rather be seen as a radicalisation of some traditional journalistic routines in the production of news. A radicalization that indicates that news in the Digital Age can be seen as a dynamic process rather than a static product. 